\title{
Estradiol up-regulates estrogen receptor messenger ribonucleic acid in endometrial carcinoma (Ishikawa) cells by stabilizing the message
}

\author{
J A Robertson ${ }^{1}$, Y Farnell ${ }^{1}$, L S Lindahl ${ }^{1}$ and $\mathbf{N}$ H Ing ${ }^{1,2}$ \\ ${ }^{1}$ Department of Animal Science, Texas A\&M University, College Station, Texas 77843-2471, USA \\ ${ }^{2}$ Department of Veterinary Anatomy and Public Health, Center for Environmental and Rural Health, and Center for Animal Biotechnology and \\ Genomics, Institute of Biosciences and Technology, Texas A\&M University System Health Sciences Center, Texas 77843-4458, USA \\ (Requests for offprints should be addressed to N H Ing, Department of Animal Science, Texas A\&M University, MS 2471, College Station, \\ TX 77843-2471, USA; Email: ning@cvm.tamu.edu)
}

\begin{abstract}
Estrogens up-regulate expression of the estrogen receptor alpha (ER) gene in most mammalian tissues studied. Using the ovariectomized ewe as a model, we determined that estradiol $\left(E_{2}\right)$ acted post-transcriptionally to increase endometrial ER mRNA concentrations by enhancing the stability of the message. The purpose of this study was to determine whether a similar $E_{2}$ effect occurs in Ishikawa cells, a well-differentiated human endometrial adenocarcinoma cell line. The presence and function of ER protein in Ishikawa cells was demonstrated by transactivation of a transfected plasmid (ERE $\left.{ }_{2} \mathrm{tkCAT}\right)$ in response to $10^{-9} \mathrm{M} \mathrm{E}_{2}$, resulting in a 550\% increase in reporter gene RNA. Ishikawa cells also responded to $E_{2}$ by up-regulating their ER mRNA concentration an average of $100 \%$ between 7 and $24 \mathrm{~h}$ of treatment. The effect of $E_{2}$ on ER mRNA stability was measured after blocking transcription with actinomycin $\mathrm{D}$ to find that the half-life increased from 6 to $10 \mathrm{~h}$ in control and $\mathrm{E}_{2}$-treated cells respectively. These results are consistent with cell-free studies which showed significant enhancement of the half-life of radiolabeled ER $3^{\prime}$ untranslated region ( $3^{\prime} U T R$ ) RNA in extracts from $E_{2}$-treated cells versus those from control cells. Thus, Ishikawa cells provide a relevant model system for the study of $E_{2}$-regulated endometrial gene expression.
\end{abstract}

Journal of Molecular Endocrinology (2002) 29, 125-135

\section{Introduction}

During times of natural estrogen dominance, both estrogen receptor alpha (ER) mRNA and protein levels increase in endometrium in species ranging from rodents to humans (Lessey et al. 1988, Brenner et al. 1991, Bergman et al. 1992, Geisert et al. 1993, Ott et al. 1993, Zheng et al. 1996). Similarly, physiological doses of estradiol $\left(\mathrm{E}_{2}\right)$ up-regulate endometrial ER gene expression in ovariectomized animals (Bergman et al. 1992, Okulicz et al. 1990, Ing et al. 1996). Our previous work showed that $\mathrm{E}_{2}$ up-regulated ER mRNA levels $400 \%$ in $24 \mathrm{~h}$ by a post-transcriptional mechanism: by stabilizing the ER message without affecting the rate of ER gene transcription (Ing et al. 1996, Ing \& Ott 1999). ER
mRNA (6500 bases long) is unstable because of its 4000 base long $3^{\prime}$ untranslated region (3'UTR) which contains many AUUUA motifs, as do the typically unstable proto-oncogene mRNAs (Keaveney et al. 1993, Kenealy et al. 2000). Therefore, $\mathrm{E}_{2}$ may stabilize endometrial ER mRNA similar to the way it stabilizes egg protein mRNAs in the livers of egg-laying animals: by inducing proteins that bind to specific sequences in the 3'UTR (Flouriot et al. 1996, Dodson \& Shapiro 1997).

In order to define the molecular mechanisms by which $\mathrm{E}_{2}$ up-regulates ER mRNA in endometrium, a physiologically relevant cell culture system is required to be able to mutate ER mRNA sequences and analyze resultant effects on stability in a living 
system. Literature searches found no reports of estrogen up-regulation of ER gene expression in any cell line derived from endometrium. In fact, expression of ER and progesterone receptor $(\mathrm{PR})$ genes is commonly lost when uterine cells are placed in culture (Helftenbein et al. 1991). The most common model for studying autoregulation of ER gene expression is the MCF7 breast cancer cell line. However, it shows down-regulation of ER mRNA and protein with $\mathrm{E}_{2}$ treatment and the effect appears to be due to reduced stability of ER mRNA (Saceda et al. 1988, Berkenstam et al. 1989, Ree et al. 1989, Borras et al. 1994, Saceda et al. 1998). This contrasts with the natural up-regulation of ER gene expression by estrogens in uterus and breast during estrous and menstrual cycles (Anderson et al. 1998).

The Ishikawa cell line, well-differentiated cells derived from a human endometrial adenocarcinoma (Nishida et al. 1985), appear to be an exception. Ishikawa cells express steroid hormone receptor genes including ER and PR. The ER $\alpha$ gene products, both mRNA and protein, predominate over those of estrogen receptor beta in Ishikawa cells as in the uterus (Kuiper et al. 1997, Paech et al. 1997, Nuttall et al. 2001, Wormke et al. 2000). In addition, Ishikawa cells maintain natural autoregulation of PR gene expression: up-regulation by $\mathrm{E}_{2}$ and down-regulation by progesterone (Holinka et al. 1986, Anzai et al. 1989, Jamil et al. 1991, Hata \& Kuramoto 1992, Lessey et al. 1996, Pinelli et al. 1998). $\mathrm{E}_{2}$ affects Ishikawa cells similar to endometrium in altering expression of alkaline phosphatase, transforming growth factors-alpha and -beta, integrins, basic fibroblast growth factor, and androgen receptor genes (Anzai et al. 1989, 1992, Lessey et al. 1996, Fujimoto et al. 1997, Lovely et al. 2000 respectively).

The purpose of this study was to determine if Ishikawa cells would provide a relevant model for future studies of the $\mathrm{E}_{2}$-induced up-regulation of ER mRNA that occurs in endometrium. Criteria were that the model should express the ER gene and respond to physiological levels of $\mathrm{E}_{2}$ by activating transcription of a reporter gene. In addition, the cultured cells should respond to $\mathrm{E}_{2}$ by up-regulating ER mRNA within $24 \mathrm{~h}$ by stabilizing the message, as does endometrium. The cell cultures that fulfill these criteria should provide a useful model system for identifying the ER mRNA sequences and binding proteins important to $\mathrm{E}_{2}$ up-regulation of $\mathrm{ER}$ gene expression.

\section{Materials and Methods}

\section{Cell culture}

Ishikawa cells were grown and maintained in DME-F12 medium containing 5\% (v/v) fetal bovine serum (FBS, Hyclone, Logan, UT, USA), $100 \mathrm{U} / \mathrm{ml}$ penicillin $\mathrm{G}$ and $100 \mu \mathrm{g} / \mathrm{ml}$ streptomycin (GIBCO/BRL, Frederick, MD, USA). Passage numbers were between 20 and 40, with cells split consistently 1:5 every other day. Three days prior to experiments, medium was changed to 'steroid-depleted medium': DME-F12 without phenol red and with 5\% dextran-charcoalstripped FBS (Hyclone) and $100 \mathrm{U} / \mathrm{ml}$ sodium penicillin $\mathrm{G}$ and $100 \mu \mathrm{g} / \mathrm{ml}$ streptomycin sulfate. At treatment initiation, cells were exposed to the indicated concentration of $\mathrm{E}_{2}$ or the drug vehicle $(0 \cdot 1 \%$ ethanol). Chemicals were of molecular biology or cell culture grade as appropriate and, unless otherwise indicated, were purchased from Sigma Chemical Co.

\section{ER activation of transfected estrogen-responsive promoter constructs}

On six-well cell culture plates, $6 \times 10^{4}$ Ishikawa cells plated the day before reached $60 \%$ confluence in steroid-depleted medium. In triplicate wells, the cells were transfected with no DNA ('mock transfection') or $1 \mu \mathrm{g}$ each of plasmids pERE $_{2}$ tkCAT (Klein-Hitpass et al. 1989) and $1 \mu \mathrm{g}$ pEGFP-C1 (Clontech) following the Superfect protocol (Qiagen). The first plasmid contained the chloramphenicol acetyltransferase (CAT) reporter gene under transcriptional control of estrogenresponse elements (EREs) to measure ER transactivation. The second plasmid contained the enhanced green fluorescent protein (EGFP) reporter gene under the transcriptional control of the cytomegalovirus promoter and was used as a control for transfection efficiency. At $18 \mathrm{~h}$ posttransfection, cells were treated with $10^{-9} \mathrm{M} \mathrm{E}_{2}$ or drug vehicle. Then $24 \mathrm{~h}$ after $\mathrm{E}_{2}$ treatment, green fluorescent cells were visualized on an Eclipse TE 300 Microscope (Nikon, Melville, NY, USA) immediately prior to RNA isolation for analysis of CAT mRNA. 


\section{Synthesis of mRNA probes}

To probe Northern blots for CAT and ER mRNAs, antisense cRNA probes were made from the pTRI-CAT DNA template (Ambion, Austin, TX, USA) and poER8 (Ing et al. 1996) respectively. For the cell-free RNA stability assays, a sense cRNA probe containing the entire 4000 base long 3'UTR of the ovine ER mRNA was synthesized from EcoR V-restricted poER-RACE2 plasmid (cDNA (GenBank accession AY033393) cloned into pCR $2 \cdot 1$ vector with the TA cloning kit (Invitrogen). As an $\mathrm{E}_{2}$-insensitive control in the cell-free stability assay, a fragment of the $28 \mathrm{~S}$ rRNA (encompassing the 989 base long HincII to BamHI fragment of the 28S rRNA cDNA; Gonsalez et al. 1985) was radiolabeled similarly. Briefly, cRNA probes were generated by in vitro transcription with T7 RNA polymerase with the Maxiscript kit (Ambion) using $\left[{ }^{32} \mathrm{P}\right] \mathrm{UTP}$ (3000 $\mathrm{Ci} / \mathrm{mmol}$, New England Nuclear, Boston, MA, USA). For Northern blots, unincorporated radionucleotides were removed from antisense probes with spin columns (Bio 101, La Jolla, CA, USA), while the sense RNAs for the cell-free stability assays were purified on 5\% acrylamide/8 M urea denaturing gels to ensure that the latter were all full-length molecules (Ing et al. 1996).

\section{Preparation of RNA samples and Northern analyses}

Total cellular RNA samples were purified from live cell cultures with Tripure Reagent (Boehringer Mannheim). Extracted RNA was resuspended in TE buffer consisting of $50 \mathrm{mM}$ Tris-Cl (pH 7·8) and $1 \mathrm{mM}$ EDTA and stored at $-80{ }^{\circ} \mathrm{C}$ pending analysis. Northern blot analyses of total cellular RNA samples $(5-8 \mu \mathrm{g}$, consistent across the set of samples to be compared on one gel and blot) were performed as previously described (Ing et al. 1996). Stringent blot hybridization $\left(55^{\circ} \mathrm{C}\right)$ and washing $\left(68^{\circ} \mathrm{C}\right)$ in $0 \cdot 1 \mathrm{X} \mathrm{SSC}(1 \mathrm{X}=150 \mathrm{mM} \mathrm{NaCl}+15 \mathrm{mM}$ $\mathrm{Na}$ citrate) containing $0 \cdot 1 \%$ SDS were followed by treatment with $1 \mu \mathrm{g} / \mathrm{ml}$ RNase A (Boehringer Mannheim) in 2X SSG for $10 \mathrm{~min}$ at room temperature. After washing twice at $55^{\circ} \mathrm{C}$ in $0 \cdot 1 \mathrm{X}$ SSC containing $0 \cdot 1 \%$ SDS for $15 \mathrm{~min}$, blots were exposed to Fuji RX autoradiographic film for times ranging from $12 \mathrm{~h}$ to 7 days in order to record hybridization signals in the linear range of the film.
The signal intensities were measured by densitometry using Adobe Photoshop (Mountain View, CA, USA) scanning and Intelligent Quantifier (BioImage, Ann Arbor, MI, USA) quantitation software. ER and CAT message sizes were confirmed as 6500 and 1350 bases by comparing migration distances to those of $28 \mathrm{~S}$ and $18 \mathrm{~S}$ rRNAs (4800 and 1800 bases respectively) on gels stained with ethidium bromide (EtBr).

\section{Inhibition of transcription by actinomycin $D$ or 5,6-dichloro-1- $\beta$-D-ribofuranosylbenzimidazole (DRB)}

In order to find the most efficacious agent for blocking transcription in Ishikawa cells, inhibition of transcription by actinomycin $\mathrm{D}$ and 5,6dichloro-1- $\beta$-D-ribofuranosylbenzimidazole (DRB) were assessed. Triplicate cultures of cells in steroid-depleted medium were exposed to actinomycin D $(5 \mu \mathrm{g} / \mathrm{ml})$ or its vehicle (ethanol to a final concentration of $0 \cdot 25 \%$ ), while others were exposed to DRB $(75 \mu \mathrm{g} / \mathrm{ml})$ or its vehicle (dimethylsulfoxide to a final concentration of $0 \cdot 1 \%)$. After $30 \mathrm{~min}$ of transcription inhibitor treatment, $5 \mathrm{mCi}$ of $[5,6-$ ${ }^{3} \mathrm{H}$ ] uridine (40 Ci/mmol; New England Nuclear) was added to the medium for pulse-labeling of nascent RNA. Three hours later the medium was changed to 'chase' medium containing $2.5 \mathrm{mM}$ unlabeled uridine and cytidine in addition to the transcription inhibitor. Cells were harvested $6 \mathrm{~h}$ after the addition of the $\left[{ }^{3} \mathrm{H}\right]$ uridine, and RNA was immediately extracted using the Tripure Reagent. Total cellular RNA $(10 \mu \mathrm{g})$ from each sample was used to purify poly $(\mathrm{A})^{+}$RNA in duplicate preparations (Kingston 1997, Ing \& Ott 2000). Incorporation of $\left[{ }^{3} \mathrm{H}\right]$ uridine into poly $(\mathrm{A})^{+} \mathrm{RNA}$ was determined by scintillation counts of $10 \mu \mathrm{l}$ aliquots of the poly $(\mathrm{A})^{+}$preparations.

\section{ER mRNA stability assays in Ishikawa cells}

Triplicate cultures of cells were cultured in steroid-depleted medium with $10^{-9} \mathrm{M} \mathrm{E}_{2}$ or drug vehicle for $24 \mathrm{~h}$. At time $0 \mathrm{~h}$, medium was exchanged for that containing $5 \mu \mathrm{g} / \mathrm{ml}$ actinomycin $\mathrm{D}$ plus $\mathrm{E}_{2}$ or $0 \cdot 1 \%$ ethanol. RNA samples were prepared from each of three triplicate cultures of 
$\mathrm{E}_{2}$-treated and untreated cells at time $0,3,6,9$ and $12 \mathrm{~h}$. Northern analysis of ER mRNA was performed as described above.

\section{Cell-free RNA stability analysis}

High speed cytosolic extracts were prepared at $4{ }^{\circ} \mathrm{C}$ (Ratnasabapathy et al. 1990, Margot \& Williams 1996) from Ishikawa cells treated for $24 \mathrm{~h}$ with $10^{-9} \mathrm{M} \mathrm{E} \mathrm{E}_{2}$ or its vehicle, $0 \cdot 1 \%$ ethanol. Briefly, $8 \times 10^{6}$ cells were homogenized in $400 \mu \mathrm{l}$ of buffer containing $10 \mathrm{mM}$ HEPES $(\mathrm{pH}$ $7.9), \quad 1.5 \mathrm{mM} \quad \mathrm{MgCl}_{2}, \quad 10 \mathrm{mM} \mathrm{KCl}, \quad 0.5 \mathrm{mM}$ dithiothreitol (DTT), and three protease inhibitors: $5 \mu \mathrm{g} / \mathrm{ml}$ aprotinin and $5 \mu \mathrm{g} / \mathrm{ml}$ leupeptin, $0.5 \mathrm{mM}$ phenylmethylsulfonylfluoride. Large particles were removed by centrifugation at $800 \boldsymbol{g}$ for $10 \mathrm{~min}$. Then $0 \cdot 11$ volumes of buffer containing $30 \mathrm{mM}$ HEPES (pH 7.9), $30 \mathrm{mM} \mathrm{MgCl}_{2}, 1 \cdot 4 \mathrm{M}$ $\mathrm{KCl}$ and protease inhibitors were added and the extracts were centrifuged at $100000 \boldsymbol{g}$ for $60 \mathrm{~min}$ to remove nuclei and cell debris. The cytosolic extracts were dialyzed against 80 volumes of buffer containing $20 \mathrm{mM}$ HEPES (pH 7.9), 20\% glycerol, $\quad 0.2 \mathrm{mM}$ ethylenediaminetetraacetate, $100 \mathrm{mM} \mathrm{KCl}$, and protease inhibitors. Protein concentrations of extracts were determined using the Bio-Rad Protein Assay (BioRad). Aliquots of extracts were stored at $-80^{\circ} \mathrm{C}$ until they were analyzed for the in vitro stability of the $3^{\prime} \mathrm{UTR}$ of the ER mRNA (Prokcipak et al. 1994, Margot \& Williams 1996).

Cell-free RNA stability assays consisted of incubating cytosolic extracts $(2 \cdot 5 \mu \mathrm{g}$ protein) from $\mathrm{E}_{2}$-treated or untreated Ishikawa cells with a radiolabeled ER 3'UTR or 28S RNA (1000 c.p.m.) in $10 \mathrm{mM}$ Tris $(\mathrm{pH} 7 \cdot 5), 60 \mathrm{mM} \mathrm{KCl}, 2 \mathrm{mM} \mathrm{Mg}$ acetate, $2 \mathrm{mM}$ DTT, $10 \%$ glycerol, $2.5 \mu \mathrm{g} / \mu \mathrm{l}$ yeast tRNA, and $0.4 \mathrm{mM}$ spermine for $30 \mathrm{~min}$ at $37^{\circ} \mathrm{C}$. After reactions were treated with proteinase $\mathrm{K}$, proteins were denatured in urea buffer and RNA was extracted with phenol-chloroform and precipitated with ethanol (Klein-Hitpass et al. 1990). Intact and degraded RNAs were separated on $1.5 \mathrm{~mm}$ thick denaturing 5\% polyacrylamide gels (Bernstein et al. 1992). Gels were dried and directly quantitated for the remaining intact ER RNA (migrating at the position of the full length RNA probe) on an InstantImager (Packard, Meriden, GT, USA).

\section{Statistical analyses}

Quantitative data were analyzed by Student's $t$-test (transfection assay and in vitro stability data), one-way ANOVA ( $\mathrm{E}_{2}$ dose and time-course data), and least squares ANOVA (transcription inhibitor trials) using SAS software (version $6 \cdot 12$ from the SAS Institute, Cary, NC, USA). Data are presented as means \pm S.E. In Northern blot analyses, the hybridization signal of the ER mRNA band was divided by the intensity of the EtBr staining of the $18 \mathrm{~S}$ rRNA in each lane (determined by densitometry) to normalize for the amount of RNA loaded. ER RNA half-lives (times to $50 \%$ of original concentrations) were estimated from semilogarithmic plots (Figs 4 and 6) of relative ER RNA levels on the $y$-axis (logarithmic) graphed against times on the $x$-axis (linear). The assumption that the RNA degrades with first-order kinetics was made (Hargrove et al. 1991). Throughout the paper, $P<0.05$ was considered as the level of significance.

\section{Results}

\section{ER protein is functional in Ishikawa cells}

Because some reports in the literature have indicated a low or absent $\mathrm{E}_{2}$ response in Ishikawa cells (Lee et al. 2000, Mueller et al. 2000), transfections were performed with an estrogenresponsive reporter plasmid, $\mathrm{pERE}_{2} \mathrm{tkCAT}$, to assess the presence and function of ER protein in our cell cultures. Transfection efficiency was high and consistent across cultures, with about 25\% of the cells demonstrating green fluorescence resulting from EGFP produced from the cotransfected pEGFP-C1 plasmid. RNA samples were analyzed for CAT RNA on Northern gels and subsequent blots. Representative analyses from mock transfections (no plasmid) and transfected cells treated with drug vehicle or $\mathrm{E}_{2}$ are shown in lanes 1-3, respectively, of Fig. 1. The EtBr-stained gel in the left panel confirmed equivalent loading across the lanes by the consistent brightnesses of the 18S rRNA bands in each lane. The autoradiographic results of the blot after hybridization to CAT cRNA probe (right panel) showed strong signals in transfected cells treated with $\mathrm{E}_{2}$ (lane 3). Hybridization occurred on regions relating to RNA molecules of 1350 bases ('CAT RNA') and 1800 bases in length. CAT RNA hybridization signals 


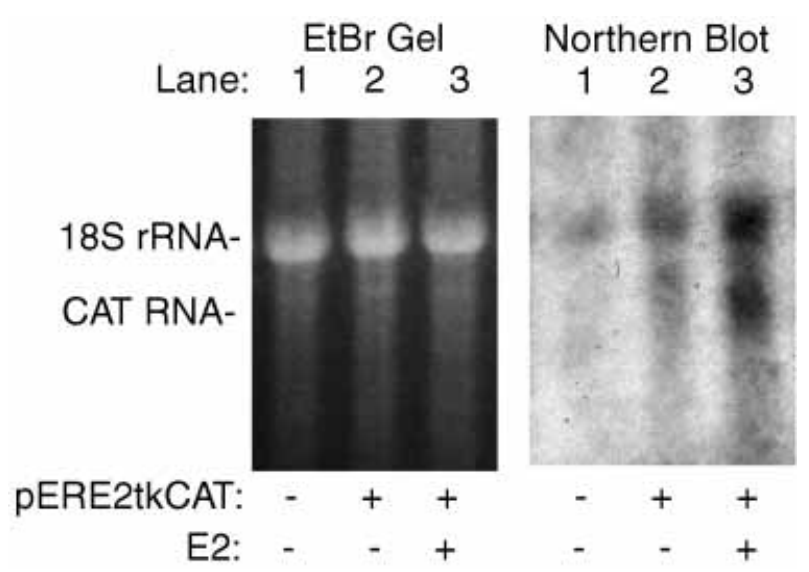

Figure 1 Transient transfection of $p E R E_{2} t k C A T$ demonstrates ER function. Ishikawa cells cultured in medium containing 5\% FBS were plated in phenol red-free medium containing 5\% charcoal-dextranstripped FBS ('steroid-depleted medium') in six-well plates. After $48 \mathrm{~h}$ in the latter, triplicate cultures of cells were transfected with $1 \mu \mathrm{g}$ each of $\mathrm{pERE_{2 }}$ tkCAT and pEGFP-C1 using the Superfect transfection reagent protocol. Mock transfection controls were treated similarly but lacked plasmid DNAs. Eighteen hours after transfection, cells were treated with $10^{-9} \mathrm{M} \mathrm{E}_{2}$ or vehicle $(0.1 \%$ ethanol) for $24 \mathrm{~h}$. Representative data are shown for three RNA samples: from mock-transfected cells (lane 1), and $p E R E_{2}$ tkCAT-transfected cells without and with $E_{2}$ treatment (lanes 2 and 3 respectively). The EtBr-stained gel shows equivalent brightnesses of $18 \mathrm{~S}$ rRNA bands, indicating equal loading of RNA in each lane ('EtBr Gel', left panel). The results from Northern blot hybridization to CAT MRNA probe (right panel) show major signals in the RNA from $E_{2}$-treated transfected cells (lane 3 ), with much lower signals in lanes 1 and 2. The migration positions of the two hybridization signals correlate to 1350 bases ('CAT RNA') and 1800 bases ('18S rRNA'). Results from replicate experiments were averaged to show that $E_{2}$ increased CAT mRNA by $550 \%$ in transfected Ishikawa cells.

were much weaker in RNA samples from transfected cells lacking $\mathrm{E}_{2}$ treatment (lane 2) and were absent in those from mock-transfected cells (lane 1). Since the signals at 1800 bases comigrated with $18 \mathrm{~S}$ rRNA and were present even in mock-transfected cells, it was designated ' $18 \mathrm{~S}$ rRNA' and presumed to be non-specific. Densitometric analyses of the CAT RNA bands in Northern blots from two experiments showed that $\mathrm{E}_{2}$ treatment of Ishikawa cells transfected with $\mathrm{pERE}_{2} \mathrm{tkCAT}_{\mathrm{T}}$ induced a $550 \%$ increase in CAT mRNA in transfected cells $(P<0 \cdot 05)$. This indicated that ER protein was both present and functional in our Ishikawa cells: it bound $\mathrm{E}_{2}$ and activated transcription of the CAT reporter gene through its upstream pair of ERE sites.

\section{$E_{2}$ up-regulates steady-state levels of ER mRNA in Ishikawa cells}

To determine if $\mathrm{E}_{2}$ up-regulates $\mathrm{ER}$ mRNA in Ishikawa cells as it does in the endometrium of sheep, Ishikawa cells were grown in steroiddepleted medium for 3 days. Triplicate cell cultures were then treated for $24 \mathrm{~h}$ with $\mathrm{E}_{2}: 10^{-10}, 10^{-9}$ or $10^{-8} \mathrm{M} \mathrm{E}_{2}$, or the $\mathrm{E}_{2}$ vehicle $(0 \cdot 1 \%$ ethanol; ' $\left.0 \mathrm{M} \mathrm{E} \mathrm{E}_{2}{ }^{\prime}\right)$. Samples of total cellular RNA were analyzed on Northern blots for ER mRNA concentration by hybridization to a radiolabeled ER cRNA probe. Hybridization signals of ER mRNA at a migration position of 6500 bases (Ing et al. 1996) increased significantly $(P<0 \cdot 05)$ with $10^{-9}$ and $10^{-8} \mathrm{M} \mathrm{E}_{2}$ treatments to levels about $50 \%$ higher than in vehicle-treated controls (Fig. 2). The $10^{-10} \mathrm{M} \mathrm{E}_{2}$ treatment showed no effect on ER mRNA levels. In three additional experiments, $10^{-8} \mathrm{M} \mathrm{E} \mathrm{E}_{2}$ significantly increased the concentration of ER mRNA even more: to $100 \%$ greater levels than in vehicle-treated control cells (data not shown).

To determine the earliest time of the increase in ER mRNA, RNA was prepared from cell cultures after the addition of $\mathrm{E}_{2}$ at $0,1,4,7$ and $10 \mathrm{~h}$. The Northern blot analyses indicated that ER mRNA concentrations significantly increased at 7 and $10 \mathrm{~h}$ post- $\mathrm{E}_{2}(P<0.05$; Fig. 3). The levels of ER mRNA increased $150 \%$ over those in control (time $=0 \mathrm{~h}$ ) cells, a magnitude similar to that found in cells treated for $24 \mathrm{~h}$ (above).

\section{$E_{2}$ stabilizes ER mRNA in Ishikawa cells: in vivo assays with inhibitors of transcription}

Inhibition of mRNA transcription in cells with actinomycin D or DRB allows measurements of cellular RNAs over a subsequent time course to estimate their molecular stabilities. Two compounds with different modes of action are routinely used to block transcription: actinomycin D intercalates the DNA template, while DRB inhibits the transcription elongation factor TFIIH (Yankulov et al. 1995). In order to find the most efficacious agent in our cell system, we evaluated the inhibition of $\left[{ }^{3} \mathrm{H}\right]$ uridine incorporation into 


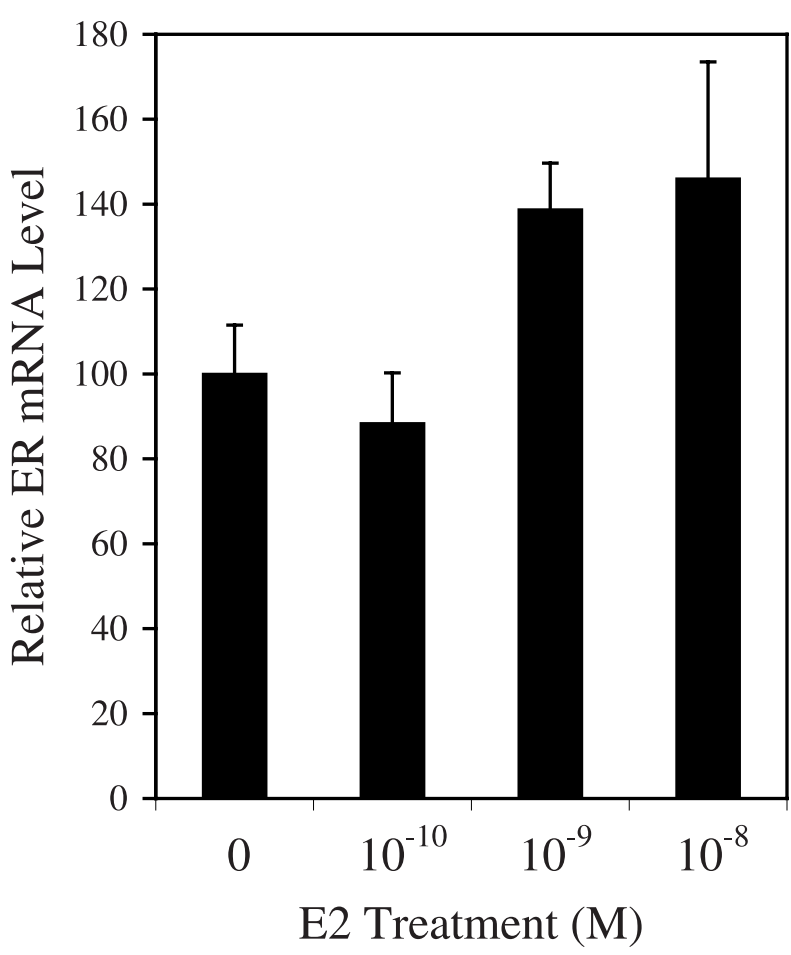

Figure $2 E_{2}$ regulation of ER mRNA levels in Ishikawa cells is dose-dependent. Ishikawa cells cultured as described in Fig. 1 were treated with $E_{2}$ at the indicated doses. The drug vehicle, $0.1 \%$ ethanol, was applied to the controls (' $0 \mathrm{M}$ treatment'). After $24 \mathrm{~h}$ of treatment, RNA was harvested from triplicate cultures, each with approximately $10^{6}$ cells, and analyzed individually for ER mRNA on Northern blots. Levels of ER mRNA are reported as least squares means and standard errors relative to the ' $0 \mathrm{M}$ ' dose treatment set at 100 for three replicate experiments. $E_{2}$ treatment at $10^{-9}$ and $10^{-8} \mathrm{M}$ doses significantly increased ER mRNA levels $(P<0.05)$ while $10^{-10} \mathrm{M} \mathrm{E}_{2}$ had no effect.

$\operatorname{poly}(\mathrm{A})^{+}$RNA in Ishikawa cells treated with actinomycin D $(5 \mu \mathrm{g} / \mathrm{ml})$ or DRB $(75 \mu \mathrm{g} / \mathrm{ml})$. Actinomycin D inhibited 93\% while DRB blocked $50 \%$ of radiolabel incorporation compared with that in cultures treated with the respective drug's vehicle. Because of its higher efficacy, we used actinomycin D to inhibit transcription for our in vivo stability assays.

Ishikawa cells grown in steroid-depleted medium were treated with $10^{-9} \mathrm{M} \mathrm{E}_{2}$ or vehicle for $24 \mathrm{~h}$. At that time (time $=0 \mathrm{~h}), 5 \mu \mathrm{g} / \mathrm{ml}$ actinomycin D was added to the medium of every cell culture. Total RNA was extracted from cells harvested at $3 \mathrm{~h}$ intervals and analyzed for ER mRNA concentrations on Northern blots. To contrast relative degradation rates, initial concentrations of

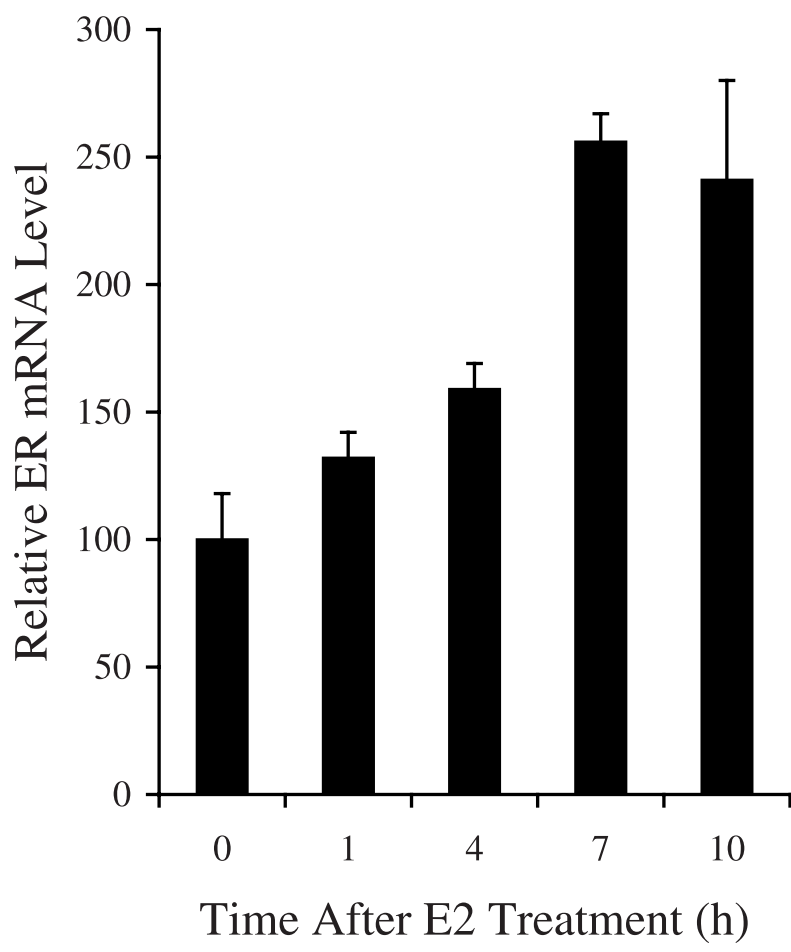

Figure 3 Time course of $E_{2}$ up-regulation of ER mRNA. Ishikawa cells were cultured as described in Fig. 1, then treated with $10^{-9} \mathrm{M} \mathrm{E}_{2}$ as described in the Methods. Cells were harvested at time of $E_{2}$ treatment initiation (' $O \mathrm{~h}$ '), and at time points $1,4,7$ and $10 \mathrm{~h}$ subsequent to it. Total cellular RNA was extracted from triplicate cultures of cells at the time of their harvest. Northern analyses indicated relative ER mRNA levels, reported as least squares means and standard errors, with the average hybridization signal of the RNA from the time ' 0 h' cultures set at 100 . ER mRNA levels increased significantly at 7 and $10 \mathrm{~h}$ post-treatment $(P<0.05)$.

ER mRNA were set at $100 \%$ for each treatment group. Figure 4 shows that the degradation of ER mRNA over time after transcription blockade occurred much faster in control cells ('No $\mathrm{E}_{2}{ }^{\prime}$ ) compared with that in the $\mathrm{E}_{2}$-treated (' $\left.\mathrm{E}_{2}{ }^{\prime}\right)$ cells. $\mathrm{E}_{2}$ treatment significantly increased $(P<0.05)$ the half-life (time to reduction to $50 \%$ of original levels) of the ER message from $6 \mathrm{~h}$ in control cells to $10 \mathrm{~h}$ in $\mathrm{E}_{2}$-treated cells.

\section{$E_{2}$ treatment of Ishikawa cells stabilizes ER RNA: cell-free stability assays}

In vitro transcription of the 3'UTR of the ER message provided a radiolabeled probe to assess 


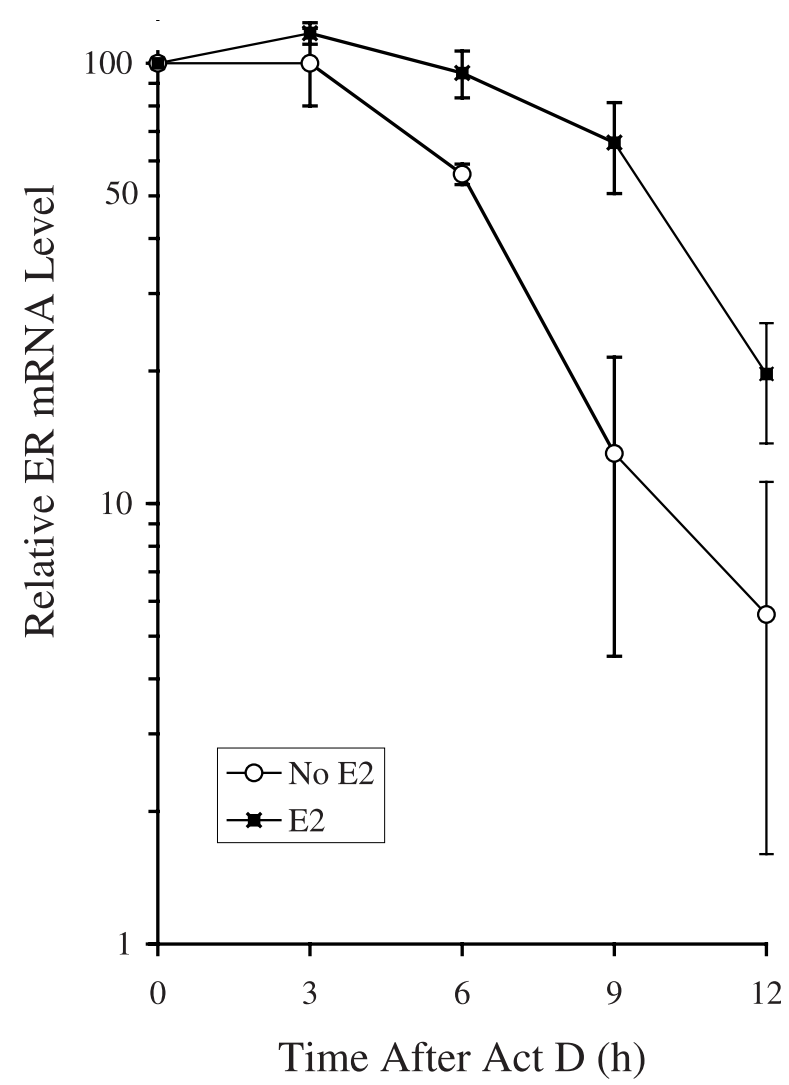

Figure $4 \mathrm{E}_{2}$ enhances ER mRNA stability in Ishikawa cells. Ishikawa cells were treated with $10^{-9} \mathrm{M} \mathrm{E}_{2}$ or vehicle $(0.1 \%$ ethanol) for $24 \mathrm{~h}$. Then, at time ' $0 \mathrm{~h}$ ', actinomycin $D(5 \mu \mathrm{g} / \mathrm{ml})$ was added to the medium to inhibit transcription. Triplicate plates of $10^{6}$ cells were harvested at 0, 3, 6, 9 and $12 \mathrm{~h}$ time points. RNA was prepared from each plate and analyzed for ER mRNA on Northern blots. Relative levels of ER mRNA at each time point are presented as a percentage of the average time 0 value for the treatment group: vehicle-treated cells ('No $E_{2}$ ', open circles) and $E_{2}$-treated cells (' $E_{2}$ ', filled squares). Least squares means and standard errors are from three replicate experiments. $E_{2}$ treatment of Ishikawa cells significantly stabilized ER mRNA from a half-life (time to $50 \%$ of initial concentration) of $6 \mathrm{~h}$ to one of $10 \mathrm{~h}(P<0.05)$.

whether the RNA was more stable in cytosolic extracts from $\mathrm{E}_{2}$-treated Ishikawa cells $(24 \mathrm{~h}$ with $10^{-9} \mathrm{M} \mathrm{E}_{2}$ ) compared with extracts from untreated cells. After a 30-min incubation of probe and extract at $37^{\circ} \mathrm{C}$, degradation of the radiolabeled probe was analyzed on a denaturing acrylamide gel (Fig. 5). The two lanes at left show the migration of duplicate samples of the intact 4000 base ER RNA probe ('Input') near the starting point of electrophoresis (upper thin arrow). The two middle lanes

\section{Input Ishikawa}

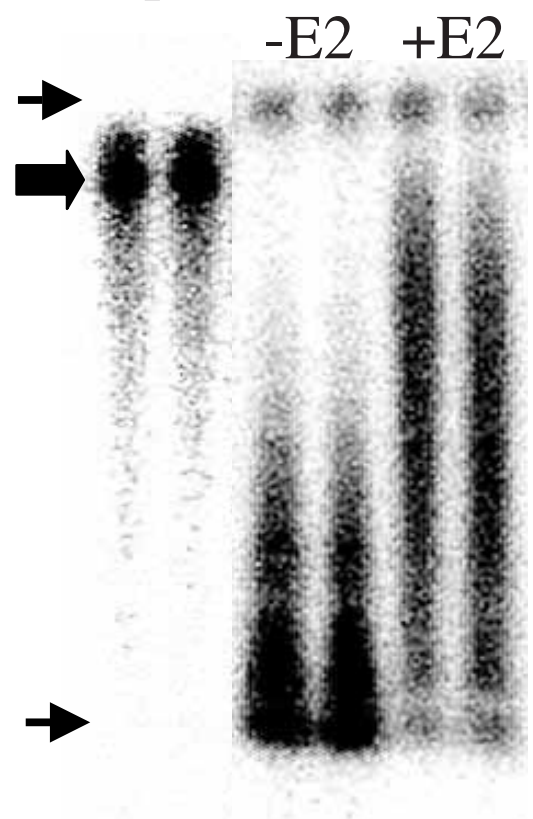

Figure 5 ER RNA stability is enhanced in extracts from $\mathrm{E}_{2}$-treated Ishikawa cells. High-speed cytosolic extracts prepared from Ishikawa cells were incubated with radiolabeled ER RNA encompassing the entire $3^{\prime} U T R$ at $37^{\circ} \mathrm{C}$ for $30 \mathrm{~min}$ in buffer conditions described in the text. This Figure shows direct scanning results of RNA analysis on a denaturing $5 \%$ acrylamide gel. Lanes (left to right) contained duplicate samples of unincubated ER RNA ('Input') and ER RNA incubated with untreated ('Ishikawa- $E_{2}$ ') and $E_{2}$-treated ('Ishikawa+ $E_{2}$ ') cell extracts. The full-length ER RNA in the left lanes (4000 bases long, migration position indicated by thick arrow) was rapidly degraded to short fragments in extracts from untreated cells (near the bottom of the gel in the middle lanes, indicated by the lower thin arrow at left). $E_{2}$ treatment of cells, however, greatly reduced degradation of the ER RNA (right lanes) so more RNA migrated less far from the wells (upper thin arrow). These are representative results from three replicate experiments.

show severe degradation of the RNA probe to small fragments that migrate near the dye front of electrophoresis (lower thin arrow), a result of incubation with extract from untreated Ishikawa cells ('Ishikawa-E ${ }_{2}$ '). In contrast, the duplicate RNA samples in the right lanes show much less degradation of the probe after incubation with the extract from $\mathrm{E}_{2}$-treated Ishikawa cells $\left(\right.$ 'Ishikawa $+\mathrm{E}_{2}$ '). Multiple experiments were analyzed for the percentage of intact RNA probe 


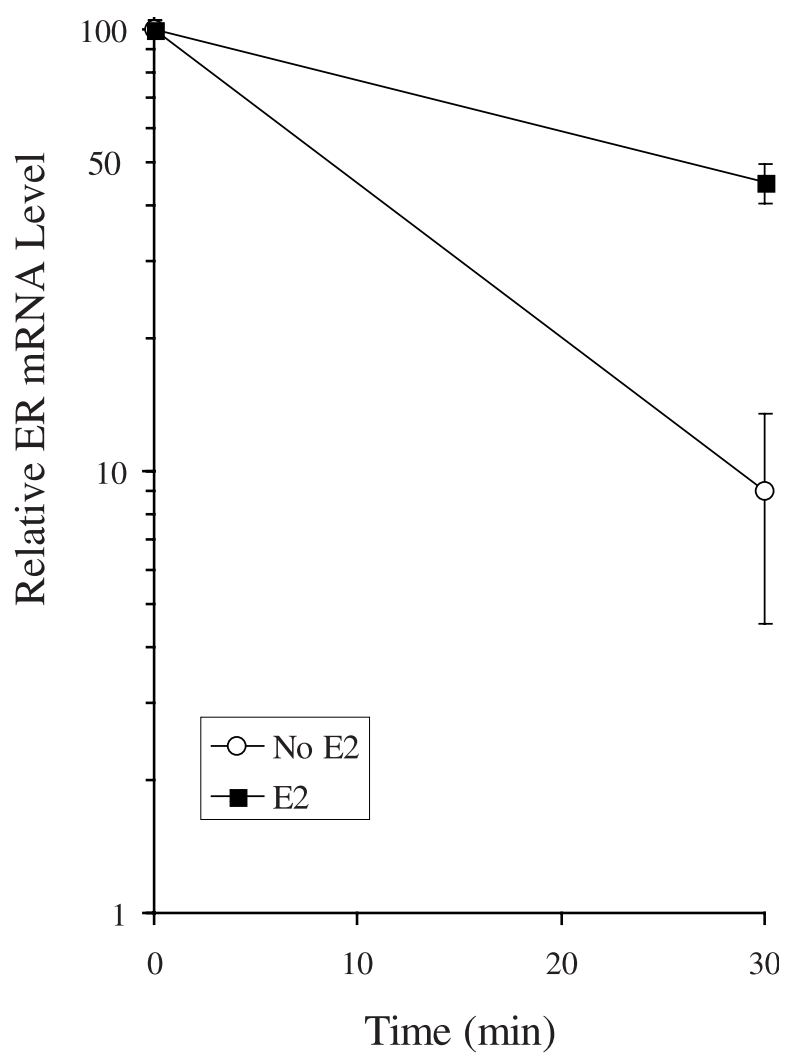

Figure $6 \mathrm{E}_{2}$ increases ER RNA half-life in Ishikawa cell extracts. ER RNA half-lives were determined with data from three replicate experiments, including the one shown in Fig. 5. Least squares means and standard errors for percentages of ER 3'UTR RNA probe remaining after 0 - and 30-min incubations with cell extracts from untreated ('No $E_{2}{ }^{\prime}$ ) and $E_{2}$-treated (' $E_{2}{ }^{\prime}$ ) Ishikawa cells were plotted as in Fig. 4. $E_{2}$ treatment increased ER RNA half-life (time to $50 \%$ of initial concentration) significantly $(P<0.05)$, from 7.5 to $30 \mathrm{~min}$.

(migrating at the position of the full length RNA probe) remaining after the incubations. $\mathrm{E}_{2}$ treatment significantly increased $(P<0 \cdot 001)$ the percentage of intact RNA remaining from $9 \pm 4 \cdot 7 \%$ in controls to $45 \pm 4 \cdot 4 \%$. The half-lives of ER RNA in $\mathrm{E}_{2}$-treated and untreated cell extracts were estimated from a semilogarithmic plot of the data (Fig. 6). $\mathrm{E}_{2}$ significantly increased ER RNA half-life, from $7 \cdot 5$ to $30 \mathrm{~min}$. This $\mathrm{E}_{2}$ effect was specific for ER RNA because a $28 \mathrm{~S}$ rRNA probe was equally stable in extracts from control and $\mathrm{E}_{2}$-treated Ishikawa cells, with $72 \%$ of the latter probe remaining intact after incubation in either extract (data not shown).

\section{Discussion}

This is the first report of $\mathrm{E}_{2}$ up-regulating $\mathrm{ER}$ gene expression in an endometrial cell line. Only one ex vivo system of endometrial cell culture has previously recapitulated the in vivo up-regulation of ER gene expression by $\mathrm{E}_{2}$ (Xiao \& Goff 1999). Those were primary cultures of epithelial cells from bovine endometrium, which demonstrated a 120\% increase in ER protein levels after treatment with $10^{-9} \mathrm{M} \mathrm{E}_{2}$ for 4 days. We set up similar experiments with primary cultures of sheep endometrial cells but had variable results (data not shown). As reported here, the Ishikawa cell line reliably reproduces the $\mathrm{E}_{2}$ up-regulation of $\mathrm{ER}$ gene expression that occurs in endometrium.

A conflict in the literature exists between those reporting that Ishikawa cells have little or no expression of ER gene (Mueller et al. 2000) and those who observe robust $\mathrm{E}_{2}$ responses and $\mathrm{ER}$ gene expression in their Ishikawa cells (Barsalou et al. 1998, Wormke et al. 2000). Therefore, an initial concern of ours was to demonstrate expression of the ultimate ER gene product, ER protein, in our cultures of Ishikawa cells. When we tested our Ishikawa cells for activation of the transfected $\mathrm{ERE}_{2} \mathrm{tkCAT}$ reporter gene, our data nearly matched the $700 \%$ increase in CAT gene expression in response to $2.5 \times 10^{-9} \mathrm{M} \mathrm{E}_{2}$ for $24 \mathrm{~h}$ (Wormke et al. 2000). These studies also prove that Ishikawa cells are suitable for genetic manipulations, such as transfection of foreign DNA.

Our focus then turned to $\mathrm{E}_{2}$-regulated expression of the endogenous ER gene in Ishikawa cells. The same low dose of $\mathrm{E}_{2}\left(10^{-9} \mathrm{M}\right)$ that increased expression of pERE $\mathrm{p}_{2} \mathrm{tkCAT}$ in transfected Ishikawa cells also up-regulated ER mRNA in untransfected cells. The magnitude of the $\mathrm{E}_{2}$-induced increase in ER mRNA levels in Ishikawa cells is consistent with that in the endometrium of ovariectomized ewes in response to a physiological dose of $\mathrm{E}_{2}$ (Robertson et al. 1998, Zou \& Ing 1998, Robertson et al. 2001). $\mathrm{E}_{2}$ levels of $10^{-9}$ and $10^{-8} \mathrm{M}$ have been used to up-regulate expression of the PR gene and other genes in Ishikawa cells (Holinka et al. 1986, Jamil et al. 1991, Lessey et al. 1996, Pinelli et al. 1998, Lovely et al. 2000). Both are within the physiological range of circulating estrogen concentrations in female mammals during estrous and menstrual cycles (Guillemot et al. 1993). 
Our time course study also illustrates the exquisite sensitivity of Ishikawa cells to $\mathrm{E}_{2}$, with the response reaching the peak induction within $7 \mathrm{~h}$ of treatment. We are aware of no other studies showing such a rapid effect of $\mathrm{E}_{2}$ on Ishikawa cells: others have used $24 \mathrm{~h}$ as an initial time point (Lessey et al. 1996, Wormke et al. 2000) and/or treated for 3 or more days (Holinka et al. 1986, Jamil et al. 1991, Barsalou et al. 1998, Lovely et al. 2000). The $\mathrm{E}_{2}$ response measured here was faster than the up-regulation of ER mRNA in endometrium (present at 24 but not $12 \mathrm{~h}$ post-injection; Ing et al. 1996, Ing \& Tornesi 1997). One possible reason for the faster response in cell culture is the lack of metabolism and clearance of the hormone during the treatment period.

Next, we determined whether Ishikawa cells shared a post-transcriptional mechanism of $\mathrm{E}_{2}$ response with endometrium for up-regulation of ER mRNA. The stabilities of ER mRNAs were analyzed in both transcription inhibitor and cell-free assays. The results demonstrated that $\mathrm{E}_{2}$-treatment of Ishikawa cells significantly increased ER mRNA half-life by $70 \%$ and approximately $300 \%$ in the respective assays, similar to the $170 \%$ increase in ER RNA half-life in endometrium of $\mathrm{E}_{2}$-treated ovariectomized ewes (Ing \& Ott 1999). The ER mRNA half-life in Ishikawa cells was similar to that measured in MCF7 breast cancer cells (Saceda et al. 1998). The half-lives in the cell-free assay were much shorter than those in living cells, probably due to lack of subcellular structures restricting RNase access to RNA and the lack of polyadenylation and capping on the synthetic RNA in the cell-free assay. We have seen similar differences between absolute values of half-lives of ER RNA in endometrial tissue and their cell-free extracts (Ing \& Ott 1999, NH Ing \& D Mitchell submitted). As for the Ishikawa assays reported here, the increased ER RNA stability with $\mathrm{E}_{2}$ treatment was consistent in both endometrial RNA stability assays.

Our conclusions are that the Ishikawa cell line maintains ER gene expression in culture and that the resultant ER protein powerfully activates transfected estrogen-responsive genes in a liganddependent manner. In addition, Ishikawa cells up-regulate the expression of their ER genes in response to $\mathrm{E}_{2}$ by a post-transcriptional mechanism, as endometrium does in vivo. By transfecting reporter genes linked to ER mRNA sequences, the elements that confer its $\mathrm{E}_{2}$-modulated stability can now be defined in this physiologically relevant model system. Functional comparisons to the $\mathrm{E}_{2}$ modulated stability of vitellogenin mRNA, sequences and the binding protein 'vigilin' that post-transcriptionally regulate gene expression in frog and chicken liver (Dodson \& Shapiro 1997) may link this ancient mechanism of $\mathrm{E}_{2}$ action to ER mRNA regulation in a mammalian cell.

\section{Acknowledgements}

The authors gratefully acknowledge kind gifts of the Ishikawa cells from Dr BA Lessey (Department of Obstetrics and Gynecology, University of North Carolina at Chapel Hill) and $\mathrm{pERE}_{2} \mathrm{tkCAT}_{\mathrm{k}}$ from Drs Ming-Jer Tsai and Sophia Tsai (Department of Cell and Molecular Biology, Baylor College of Medicine), as well as the outstanding technical assistance provided by Cindy Balog. Research was conducted through the Texas Agricultural Experiment Station with funding provided by grants to N.H.I. from the USDA/C.SREES (NRI-GGP 98-35203-6272) and to JR from the Lalor Foundation.

\section{References}

Anderson E, Clarke RB \& Howell A 1998 Estrogen responsiveness and control of normal human breast proliferation. Fournal of Mammary Gland Biology and Neoplasia 3 23-35.

Anzai Y, Holinka CF, Kuramoto H \& Gurpide E 1989 Stimulatory effects of 4-hydroxytamoxifen on proliferation of human endometrium adenocarcinoma cells (Ishikawa Line). Cancer Research 49 2362-2365.

Anzai Y, Gong Y, Holinka CF, Murphy LJ, Murphy LC, Kuramoto H \& Gurpide E 1992 Effects of transforming growth factors and regulation of their mRNA levels in two human endometrial adenocarcinoma cell lines. Fournal of Steroid Biochemistry and Molecular Biology 42 449-455.

Barsalou A, Gao W, Anghel SI, Carriere J \& Mader S 1998 Estrogen response elements can mediate agonist activity of anti-estrogens in human endometrial Ishikawa cells. Fournal of Biological Chemistry 273 17138-17146.

Bergman MD, Schachter BS, Karelus K, Combatsiaris EP, Garcia T \& Nelson JF 1992 Up-regulation of the uterine estrogen receptor and its messenger ribonucleic acid during the mouse estrous cycle: the role of estradiol. Endocrinology 130 1923-1930.

Berkenstam A, Glaumann H, Martin M, Gustafsson J-A \& Norstedt G 1989 Hormonal regulation of estrogen receptor messenger ribonucleic acid in $\mathrm{T}_{47} 7 \mathrm{D}_{\mathrm{co}}$ and $\mathrm{MCF}-7$ breast cancer cells. Molecular Endocrinology 3 22-28.

Bernstein PL, Herrick DJ, Prokipcak RD \& Ross J 1992 Control of c-myc mRNA half-life in vitro by a protein capable of binding to a coding region stability determinant. Genes and Development 6 $642-654$ 
Borras M, Hardy L, Lempereur F, El Khissiin AH, Legros N, Gol-Winkler R \& Leclercq G 1994 Estradiol-induced down-regulation of estrogen receptor: effect of various modulators of protein synthesis and expression. Fournal of Steroid Biochemistry and Molecular Biology 48 325-336.

Brenner RM, McClellan MC, West NB, Novy MJ, Haluska GJ \& Sternfeld MD 1991 Estrogen and progestin receptors in the macaque endometrium. Annals of the New York Academy of Sciences 622 149-166

Dodson RE \& Shapiro DJ 1997 Vigilin, a ubiquitous protein, with $14 \mathrm{~K}$ homology domains, is the estrogen-inducible vitellogenin mRNA 3'-untranslated region-binding protein. Fournal of Biological Chemistry 272 12249-12252.

Flouriot G, Pakdel F \& Valotaire Y 1996 Transcriptional and post-transcriptional regulation of rainbow trout estrogen receptor and vitellogenin gene expression. Molecular and Cellular Endocrinology 124 173-183.

Fujimoto J, Hori M, Ichigo S, Hirose R \& Tamaya T 1997 Antiestrogenic compounds inhibit estrogen-induced expression of basic fibroblast growth factor and its mRNA in well-differentiated endometrial cancer cells. General Pharmacology 28 215-219.

Geisert RD, Brenner RM, Moffatt RJ, Harney JP, Yellin T \& Bazer FW 1993 Changes in oestrogen receptor protein, mRNA expression and localization in the endometrium of cyclic and pregnant gilts. Reproduction, Fertility and Development 5 247-260.

Gonsalez IL, Gorski JL, Campen TS, Dorney DJ, Erickson JM, Sylvester JE \& Schmickel RD 1985 Variation among human 28S ribosomal RNA genes. PNAS 82 7666-7670.

Guillomot M, Flechon J-E \& Leroy F 1993 Blastocyst development and implantation. In Reproduction in Mammals and Man, pp 387-410. Eds C Thibault, M-C Levasseur \& RHF Hunter. Paris: Ellipses.

Hargrove JL, Hulsey MG \& Beale EG 1991 The kinetics of mammalian gene expression. Bioessays 13 667-674.

Hata H \& Kuramoto H 1992 Immunocytochemical determination of estrogen and progesterone receptors in human endometrial adenocarcinoma cell (Ishikawa cells). Fournal of Steroid Biochemistry and Molecular Biology 42 201-210.

Helftenbein G, Misseyanni A, Hagen G, Peter W, Slater EP, Wiehle RD, Suske G \& Beato M 1991 Expression of the uteroglobin promoter in epithelial cell lines from endometrium. Annals of the New York Academy of Sciences 622 69-79.

Holinka CF, Hata H, Kuramoto H \& Gurpide E 1986 Responses to estradiol in a human endometrial adenocarcinoma cell line (Ishikawa). Fournal of Steroid Biochemistry 24 85-89.

Ing NH \& Tornesi MB 1997 Estradiol up-regulates estrogen receptor and progesterone receptor gene expression in specific ovine uterine cells. Biology of Reproduction 56 1205-1215.

Ing NH \& Ott TL 1999 Estradiol up-regulates estrogen receptor alpha messenger ribonucleic acid in sheep endometrium by increasing its stability. Biology of Reproduction 60 134-139.

Ing NH, Spencer TE \& Bazer FW 1996 Estrogen enhances endometrial estrogen receptor gene expression by a posttranscriptional mechanism in the ovariectomized ewe. Biology of Reproduction $\mathbf{5 4}$ 591-599.

Jamil A, Croxtall JD \& White JO 1991 The effect of anti-oestrogens on cell growth and progesterone receptor concentration in human endometrial cancer cells. Fournal of Molecular Endocrinology 6 215-221.

Keaveney M, Parker MG \& Gannon F 1993 Identification of a functional role for the $3^{\prime}$ region of the human estrogen receptor gene. Fournal of Molecular Endocrinology 10 143-152.

Kenealy M-R, Flouriot G, Sonntag-Buck V, Dandekar T, Brand H \& Gannon F 2000 The 3'-untranslated region of the human estrogen receptor $\alpha$ gene mediates rapid messenger ribonucleic acid turnover. Endocrinology $1412805-2813$.

Kingston RE 1997 Preparation of a poly(A) ${ }^{+}$RNA. In Current Protocols in Molecular Biology, pp 4·5·1-4·5·3. Eds FM Ausubel, R
Brent, RE Kingston, DD Moore, JG Seidman, JA Smith \& K Struhl. New York: John Wiley and Sons.

Klein-Hitpass L, Tsai SY, Greene GL, Clark JH, Tsai M-J \& O'Malley BW 1989 Specific binding of estrogen receptor to the estrogen response element. Molecular and Cellular Biology 9 43-49.

Klein-Hitpass L, Tsai SY, Weigel NL, Allan GF, Riley D, Rodriguez R, Schrader WT, Tsai M-J \& O'Malley BW 1990 The progesterone receptor stimulates cell-free transcription by enhancing the formation of a stable preinitiation complex. Cell $\mathbf{6 0}$ 247-257.

Kuiper GJM, Carlsson B, Grandien K, Enmark E, Haggblad J, Nilsson S \& Gustafsson J-A 1997 Comparison of the ligand binding specificity and transcript distribution of estrogen receptors $\alpha$ and $\beta$. Endocrinology 138 863-870.

Lee H, Jiang F, Wang Q Nicosia SV, Yang J, Su B \& Bai W 2000 MEKK 1 activation of human estrogen receptor $\alpha$ and stimulation of the agonistic activity of 4-hydroxyl tamoxifen in endometrical and ovarian cancer cells. Molecular Endocrinology 14 1882-1896.

Lessey BA, Killam AP, Metzger DA, Haney AF, Greene GL \& McCarty KS 1988 Immunohistochemical analysis of human uterine estrogen and progesterone receptor throughout the menstrual cycle. Fournal of Clinical Endocrinology and Metabolism 67 334-340.

Lessey BA, Ilesanmi AO, Castelbaum AJ, Yuan L, Somkuti SG, Satyaswaroop PG \& Chwalisz K 1996 Characterization of the functional progesterone receptor in an endometrial adenocarcinoma cell line (Ishikawa): progesterone-induced expression of the $\alpha$ integrin. Fournal of Steroid Biochemistry and Molecular Biology 59 31-39.

Lovely LP, Rao KBCA, Gui Y \& Lessey BA 2000 Characterization of androgen receptors in a well-differentiated endometrial adenocarcinoma cell line (Ishikawa). Fournal of Steroid Biochemistry and Molecular Biology 74 235-241.

Margot JB \& Williams DL 1996 Estrogen induces the assembly of a multiprotein messenger ribonucleoprotein complex on the 3' untranslated region of chicken apolipoprotein II mRNA. Fournal of Biological Chemistry 271 4452-4460.

Mueller MD, Vigne J-L, Minchenko A, Lebovic DI, Leitman DC \& Taylor RN 2000 Regulation of vascular endothelial growth factor (VEGF) gene transcription by estrogen receptors $\alpha$ and $\beta$. PNAS 97 10972-10977.

Nishida M, Kasahara K, Kaneko M, Iwasaki H \& Hayashi K 1985 Establishment of a new human endometrial adenocarcinoma cell line, Ishikawa cells, containing estrogen and progesterone receptors. Acta Obstetrics Gynaecology Japan 37 1103-1111.

Nuttall ME, Pendrak, I, Emery JG, Nadeau DP, Fisher PW, Nicholson TA, Zhu Y, Suva LJ, Kingsbury WD \& Gowen M 2001 Antagonism of oestrogen action in human breast and endometrial cells in vitro: potential novel antitumour agents. Cancer Chemotherapy and Pharmacology 47 437-443.

Okulicz WC, Savasta AM, Hoberg LM \& Longcope C 1990 Biochemical and immunohistochemical analyses of estrogen and progesterone receptors in rhesus monkey uterus during the proliferative and secretory phases of artificial menstrual cycles. Fertility and Sterility 53 913-920.

Ott TL, Zhou Y, Mirando MA, Stevens G, Harney JP, Ogle TF \& Bazer FW 1993 Changes in progesterone and oestrogen receptor mRNA and protein during maternal recognition of pregnancy and luteolysis in ewe. Fournal of Molecular Endocrinology 10 171-183.

Paech K, Webb P, Kuiper GJM, Nilsson S, Gustafsson J-A, Kushner PJ \& Scanlan TS 1997 Differential ligand activation of estrogen receptors ER $\alpha$ and ER $\beta$ at AP1 sites. Science 277 1508-1510.

Pinelli DM, Drake J, Williams MC, Cavanagh D \& Becker JL 1998 Hormonal modulation of Ishikawa cells during three-dimensional growth in vitro. Fournal of the Society for Gynecologic Investigations $\mathbf{5}$ $217-223$. 
Prokipcak RD, Herrick DJ \& Ross J 1994 Purification and properties of a protein that binds to the $\mathrm{C}$-terminal coding region of human c-myc mRNA. Fournal of Biological Chemistry 269 9261-9269.

Ratnasabapathy R, Hwang SPL \& Williams DL 1990 The 3' untranslated region of apolipoprotein II mRNA contains two independent domains that bind distinct cytosolic factors. Fournal of Biological Chemistry 265 14050-14055.

Ree AH, Landmark BF, Eskild W, Levy FO, Lahooti H, Jahnsen T, Aakvaag A \& Hansson V 1989 Autologous down-regulation of messenger ribonucleic acid and protein levels for estrogen receptor in MCF-7 cells: an inverse correlation to progesterone receptor levels. Endocrinology 124 2577-2583.

Robertson JA, Bhattacharyya S \& Ing NH 1998 Tamoxifen up-regulates oestrogen receptor- $\alpha$, c-fos and glyceraldehyde 3-phosphate dehydrogenase mRNAs in ovine endometrium. Fournal of Steroid Biochemistry and Molecular Biology 67 285-292.

Robertson JA, Zhang Y \& Ing NH 2001 ICI 182,780 acts as a partial agonist and antagonist of estradiol effects in specific cells of the sheep uterus. Foumal of Steroid Biochemistry and Molecular Biology 77 281-287.

Saceda M, Lippman ME, Chambon P, Lindsey RL, Ponglikitmongkol M, Puente M \& Martin MB 1988 Regulation of the estrogen receptor in MCF-7 cells by estradiol. Molecular Endocrinology 2 1157-1162.

Saceda M, Lindsey RK, Solomon H, Angeloni SV \& Martin MB 1998 Estradiol regulates estrogen receptor mRNA stability. Fournal of Steroid Biochemistry and Molecular Biology 66 113-120.
Wormke M, Castro-Rivera E, Chen I \& Safe S 2000 Estrogen and aryl hydrocarbon receptor expression and crosstalk in human Ishikawa endometrial cancer cells. Fournal of Steroid Biochemistry and Molecular Biology 72 197-207.

Xiao CW \& Goff AK 1999 Hormonal regulation of oestrogen and progesterone receptors in cultured bovine endometrial cells. Fournal of Reproduction and Fertility 115 101-109.

Yankulov K, Yamashita K, Roy R, Elgy JM \& Bentley DL 1995 Transcriptional elongation inhibitor 5,6-dichloro-1- $\beta$-D-ribofuranosylbenzimidazole inhibits transcription factor IIH-associated kinase. Foumal of Biological Chemistry 270 23922-23925.

Zheng J, Johnson ML, Redmer DA \& Reynolds LP 1996 Estrogen and progesterone receptors, cell proliferation, and c-fos expression in the ovine uterus during early pregnancy. Endocrinology 137 340-348.

Zou K \& Ing NH 1998 Oestradiol up-regulates oestrogen receptor, cyclophilin, and glyceraldehyde phosphate dehydrogenase mRNA concentrations in endometrium, but down-regulates them in liver. Fournal of Steroid Biochemistry and Molecular Biology 64 231-237.

Received in final form 25 February 2002 Accepted 28 February 2002 